Potret Kebidupan "Alam”: Pendidikan...

\title{
POTRET KEHIDUPAN “ALAM”: PENDIDIKAN YANG BERWAWASAN LINGKUNGAN MASYARAKAT TERASING DI KAMPUNG NAGA
}

\author{
Galuh Dwi Purwasih ${ }^{1}$ \\ (galuhdewipurwasih@gmail.com)
}

\begin{abstract}
Improving the quality of human resources (HR) is a need that can not be bargained again, especially in the face of changes and developments in the field of science and technology so rapidly. This need will be felt even more when entering the era of globalization which is highly oriented to the quality of human resources according to Busro. As it is known, the globalization of information and communication has the potential to improve human resources. The need for learning to a minimum need to be improved in isolated communities through original values that have been established and are rooted in people's lives. Local knowledge or local wisdom must be included in the education curriculum as a source of innovation and skills that can be empowered for the welfare of society. Every educational process essentially is an effort to direct and mobilize two forces; on the one hand the power to preserve and on the other hand the power to advance. Fulfilling the rights of citizens to obtain educational services, especially 9-year of basic education, the Indonesian Ministry of National Education develops two channels of education, namely education through schools and non-formal education. Non-formal education consists of package A (equivalent to elementary school), package B (equivalent to junior high school), package $\mathrm{C}$ (equivalent to senior high school) and various life skills. A non-formal education is more flexible than formal education in terms of curriculum, time, place, students and educators. A non-formal education is one of the alternatives because it does not undermine the activities of students to learn and to pursue real life in their environments.
\end{abstract}

Keyword: life, education, alienated society

\section{Abstrak}

Peningkatan kualitas sumber daya manusia (SDM) merupakan kebutuhan yang tidak dapat ditawar-tawar lagi, terutama dalam menghadapi perubahan dan perkembangan di bidang ilmu maupun teknologi yang begitu pesat. Kebutuhan tersebut akan lebih terasa lagi dalam memasuki era globalisasi yang sangat mengutamakan kualitas SDM menurut Busro. Sebagaimana diketahui, globalisasi informasi dan komunikasi memiliki potensi dalam meningkatkan Sumber Daya Manusia. Keperluan belajar secara minimum perlu ditingkatkan dalam masyarakat terasing melalui nilai-nilai asli yang telah mapan dan berakar dalam kehidupan masyarakat. Pengetahuan lokal atau kearifan lokal (local knowledge, local wisdom) harus masuk ke dalam kurikulum pendidikan sebagai sumber inovasi dan keterampilan yang dapat diberdayakan demi kesejahteraan masyarakat. Setiap proses pendidikan pada hakikatnya merupakan ikhtiar untuk mengarahkan dan mengerahkan dua daya; di satu sisi daya untuk melestarikan dan di sisi lainya daya untuk

\footnotetext{
${ }^{1}$ Dosen Sekolah Tinggi Agama Islam Badrus Sholeh Purwoasri-Kediri
}

39 | Jurnal Auladuna 


\section{Galuh Dwi Purwasih}

memajukan. Untuk memenuhi hak warga negara dalam memperoleh pengkhidmatan pendidikan, terutama pendidikan dasar 9 tahun, Departemen Pendidikan Nasional Indonesia mengembangkan dua jalur pendidikan, yakni pendidikan melalui sekolah dan pendidikan luar sekolah (non-formal). Pendidikan luar sekolah terdiri dari program Paket A (setara sekolah dasar), Paket B (setara sekolah menengah pertama), Paket C (setara sekolah menengah atas) dan berbagai keterampilan hidup. Pendidikan luar sekolah lebih fleksibel dibandingkan dengan pendidikan sekolah dari segi kurikulum, waktu, tempat, pelajar dan tenaga pendidik. Pendidikan luar sekolah menjadi salah satu alternatif kerana tidak terlalu mengekang aktivitas peserta didik untuk belajar sekaligus menekuni kehidupan nyata di lingkungannya.

\section{Kata Kunci: kehidupan, pendidikan, masyarakat terasing}

\section{PENDAHULUAN}

Anak-anak yang tinggal di daerah terasing sangat sulit mendapatkan kehidupan yang layak seperti anak-anak pada umumnya yang sudah tidak menjadi rahasia publik. Mereka kesulitan mendapatkan air bersih, mengenyam pendidikan sesuai batas kelayakan pendidikan Indonesia dan sulit mengikuti perkembangan zaman. Mereka bahkan tidak mengenal alat komunikasi seperti telepon genggam. Hal pokok yang menjadi sorotan utama yaitu betapa sulitnya mereka mendapat pendidikan yang layak dan mengenyam pendidikan dua belas tahun. Pada faktanya tak semua salah mereka, kesulitan mereka menjangkau lokasi sekolah menjadi masalah karena mereka harus mengarungi sungai. Mereka juga harus berjalan kaki hingga berpuluh-puluh kilo meter, bahkan ada pula yang tidak memakai alas kaki.

Kurangnya tenaga pengajar di daerah terasing karena sulitnya mencari pengajar yang mau mengajar di daerah tersebut juga sangat disayangkan. Padahal kualitas seseorang diukur melalui seberapa jauh pendidikan yang dicapai karena kualitas seorang lulusan SD berbeda dengan kualitas seorang sarjana, sehingga dapat disimpulkan bahwa pendidikan sangat memengaruhi kualitas seorang anak pedalaman.

Pemerintah seharusnya lebih peduli terhadap pendidikan di daerah terpencil karena semua akan berjalan dengan baik jika top manajemennya dalam hal ini pemerintah yang mampu dan mau untuk lebih peduli terhadap pendidikan di daerah terpencil. Keberadaan kepedulian pemerintah yang didukung oleh semua sarana pendidikan, maka diharapkan pendidikan di daerah terpencil tidak akan tertinggal dan akan lebih layak. Amanat Undangundang Dasar 45 pasal 31 menyebutkan: 
Potret Kebidupan "Alam": Pendidikan...

“(1) Setiap warga negara berhak mendapat pendidikan. (2) Setiap warga negara wajib mengikuti pendidikan dasar dan pemerintah wajib membiayainya. (3) Pemerintah mengusahakan dan menyelenggarakan satu sistem pendidikan nasional, yang meningkatkan keimanan dan ketakwaan serta akhlak mulia dalam rangka mencerdaskan kehidupan bangsa, yang diatur dengan Undang-Undang. (4) Negara memprioritaskan anggaran pendidikan sekurang-kurangnya dua puluh persen dari anggaran pendapatan dan belanja negara serta dari anggaran pendapatan dan belanja daerah untuk memenuhi kebutuhan penyelenggaraan pendidikan nasional."

Makna dari Pasal 31 UUD 1945 tersebut adalah setiap warga negara berhak mendapatkan pendidikan tanpa terkecuali. Pada kenyataannya, dengan kondisi negara Indonesia yang sangat luas dan terdiri dari ribuan pulau, mulai Sabang sampai Merauke, bangsa Indonesia dihadapkan dengan berbagai permasalahan pelayanan pendidikan bagi masyarakat. Padahal pendidikan merupakan faktor utama dalam menentukan kemajuan sebuah bangsa, dengan tingkat pendidikan yang tinggi, maka akan semakin baik Sumber Daya Manusia yang ada dan pada akhirnya akan semakin tinggi pula daya kreativitas pemuda Indonesia dalam mengisi pembangunan sebuah bangsa. Indonesia terlihat masih kesulitan untuk mewujudkan pendidikan yang baik dan berkualitas sesuai dengan standar nasional.

Berbagai permasalahan seringkali menghambat peningkatkan mutu pendidikan nasional, khususnya di daerah tertinggal atau terpencil, yang pada akhirnya mewarnai perjalanan pendidikan di Indonesia. Di suatu daerah terpencil masih banyak dijumpai kondisi di mana anak-anak belum terlayani pendidikannya, seperti: angka putus sekolah yang masih tinggi, masalah kekurangan guru, walaupun pada sebagain daerah, khususnya daerah perkotaan, persediaan guru malah berlebih, sarana dan prasarana yang belum memadai. Itulah sederet fakta-fakta yang menghiasai wajah pendidikan Indonesia di daerah terpencil.

Pemenuhan hak warga negara dalam memperoleh pengkhidmatan pendidikan terutama pendidikan dasar 9 tahun, Departemen Pendidikan Nasional Indonesia mengembangkan dua jalur pendidikan, yakni pendidikan melalui sekolah dan pendidikan luar sekolah (non-formal). Pendidikan luar sekolah terdiri dari program Paket A (setara sekolah dasar), Paket B (setara sekolah menengah pertama), Paket C (setara sekolah menengah atas) dan berbagai keterampilan hidup. Pendidikan luar sekolah lebih fleksibel 


\section{Galuh Dwi Purwasih}

dibandingkan dengan pendidikan sekolah dari segi kurikulum, waktu, tempat, pelajar dan tenaga pendidik.

Pembangunan pendidikan modern diharapkan tidak mengarah pada perubahan degeneratif yang dapat menimbulkan sikap apriori masyarakat terasing terhadap sekolah. Perubahan degeneratif adalah perubahan yang telah merusak keseimbangan dari kehidupan sosial suatu masyarakat dan sering kali juga merusak keseimbangan ekologi lingkungan alamnya. Koentjaraningrat dalam pandangannya mengatakan bahwa dalam pembangunan masyarakat terasing di Indonesia, sikap itu dapat mengakibatkan keadaan seperti yang terjadi pada orang Badui di Banten, atau dapat menimbulkan gerakan kargo (cargo) yang bersifat pasif maupun agresif, seperti yang terjadi pada beberapa masyarakat terasing di Irian Jaya. Program-program pembangunan yang dipaksakan dari luar, jarang sejalan dengan kebutuhan dan aspirasi suatu komunitas. Pengamatan yang dilakukan oleh Judistira pada tahun 1993 mengenai orang Badui menjelaskan bahwa komunitas Badui memiliki mekanisme sosial-kultural yang memungkinkan mereka beradaptasi dengan lingkungan yang baru dan melestarikan eksistensi mereka. Oleh itu perlu pengetahuan atau kearifan lokal (local knowledge atau local wisdom) di masukkan ke dalam kurikulum pendidikan sebagai sumber inovasi dan keterampilan yang dapat diberdayakan demi kesejahteraan masyarakat.

\section{PEMBAHASAN}

\section{Sistem Belajar Asli}

Sistem belajar asli (indigenous learning system) adalah sistem belajar yang digunakan masyarakat tradisional sebagai upaya mempertahankan dan memelihara sistem sosial masyarakatnya demi kelangsungan hidup. Sistem belajar asli secara tradisional digunakan untuk memenuhi keperluan-keperluan praktis, meneruskan warisan sosial budaya dan keterampilan serta teknologi masyarakat pedesaan dari generasi ke generasi. Pendidikan import yang merupakan suatu bentuk kebudayaan ter-alienasi atau terasing semata-mata merupakan barang tempelan bagi masyarakat yang mengimpornya. ${ }^{2}$ Paulo selanjutnya berpandangan bahwa pendidikan semacam itu bukanlah pendidikan sejati,

${ }^{2}$ Didin Saripudin, Masyarakat dan Pendidikan: Perspektif Sosiologi (Pahang: Yayasan Istana Abdulaziz, 2008)

42 | Jurnal Auladuna 
Potret Kebidupan "Alam": Pendidikan...

karena tidak berada dalam hubungan dialektis dengan konteksnya dan tidak memiliki kekuatan untuk mengubah realitas. Sistem belajar asli dalam masyarakat tradisional memiliki kekuatan sendiri. Secara minimum menurut Coombs, ada enam kebutuhan belajar yang esensial, yaitu: (1) sikap positif terhadap kerja sama sesama manusia; (2) kemampuan membaca dan berhitung yang fungsional; (3) memiliki pandangan ilmiah dan pengertian dasar proses terhadap alam; (4) pengetahuan dan keterampilan fungsional untuk mendapatkan penghasilan; (5) pengetahuan dan keterampilan untuk menghidupkan keluarga; (6) pengetahuan dan keterampilan fungsional untuk partisipasi warga negara dalam kehidupan nasional.

Keperluan belajar secara minimum perlu ditingkatkan dalam masyarakat tradisional melalui nilai-nilai asli yang telah mapan dan berakar dalam kehidupan masyarakat. Secara spesifik perlu dilihat gaya belajar, bahan dan prosedur yang membuat nenek moyang kita mampu mengembangkan kebudayaan dengan pengetahuan-pengetahuan yang berguna dan keterampilan-keterampilan serta membangun kehidupan melalui nilai-nilai asli yang telah berlangsung dan bertahan terhadap pengikisan akibat dissonant. Masyarakat tradisional telah mengembangkan sendiri pendidikan tradisi melalui sistem belajar asli dalam proses transaksi dan adaptasi antara mereka dengan lingkungannya dan terhadap dunianya. Proses belajar seperti ini dapat dipahami dengan menggunakan teori "experiential learning" yaitu belajar adalah suatu proses di mana pengetahuan dibangun melalui transformasi pengalaman.

Kolb mengemukakan empat tahapan dalam proses belajar berdasarkan pengalaman yang melibatkan cara belajar adaptif, yaitu: concrete experiences, reflective observation, abstract conceptualization, dan active experimentation. Model concrete experiences/ abstract conceptualization disatu pihak dan active experimentation/ reflective observation di lain pihak merupakan dua dimensi masing-masing mewakili dua orientasi adaptif yang berlawanan secara dialektis. Proses pendidikan semacam ini sebenarnya merupakan proses belajar yang manusiawi (sesuai dengan kodrat dan perkembangan manusia). Manusia memiliki potensi ke-empatnya, di mana proses belajar seseorang akan mencakup prosesproses, antara lain: mengalami sesuatu secara konkret, memikirkan secara konseptual, mengamati sesuatu sambil merenungkannya dan mencobakan sesuatu dalam situasi lain 


\section{Galuh Dwi Purwasih}

yang lebih luas. ${ }^{3}$ Hal ini bertolak belakang dengan proses belajar dalam konteks pendidikan sekolah yang cenderung melakukan proses belajar secara deduktif, dari proses konseptualisasi abstrak (abstract conceptualization) ke proses pengalaman konkret (concrete experience).

Setiap masyarakat yang sederhana sekalipun, pendidikan itu tumbuh sesuai dengan tuntutan dan kebutuhan melalui sistem belajar asli yang bersumber dari akar budaya masyarakatnya dan senantiasa berkembang atau berubah secara alami. Sistem dan tujuan pendidikan bagi suatu masyarakat, harus timbul dari dalam masyarakat itu sendiri, berdasarkan identitas, pandangan hidup dan nilai-nilai yang terdapat pada masyarakat tersebut. Sentuhan-sentuhan informasi dan berbagai media komunikasi yang mereka terima dapat diserap secara selektif sesuai keperluannya. Ada yang diserap seluruhnya atau sebagian saja dan ada pula yang ditolaknya bilamana bertentangan dengan sistem nilai budaya yang sudah berakar dalam masyarakatnya.

Pendidikan modern harus menjadi sarana untuk perubahan sosial dan kebudayaan, pendidikan seharusnya memperhitungkan pentingnya kesinambungan antara instruksiinstruksi di sekolah dengan kehidupan masyarakat di mana sekolah tersebut berada yang diyakini oleh Soriano. Penyebaran pendidikan sekolah dan luar sekolah ke dalam masyarakat majemuk tradisional perlu mempertimbangkan adanya pluralitas horizontal (adanya perbedaan etnik, sub-sub etnik) dan pluralitas vertical (adanya pelapisan-pelapisan sosial). Upaya mencerdaskan kehidupan bangsa melalui jalur-jalur sekolah maupun luar sekolah diharapkan benar-benar menjadi suatu keperluan masyarakat.

Pendidikan itu bertanggung jawab penuh mengenai peri kehidupan anggota masyarakat sejak awal hingga akhir hayatnya baik dalam hal etika, moral, kejiwaan, pelaksanaan ilmu pengetahuan mereka dan berbagai kemahiran atau keterampilan/ kejuruan yang senantiasa berkembang. Pendidikan merupakan harapan untuk mencerdaskan bangsa tidak semestinya hanya terpaku pada sekolah melalui rekayasa kurikulum. Peluang lain melalui pendekatan pendidikan luar sekolah untuk masyarakat di desa-desa pedalaman dan gugusan pulau-pulau terpencil geografis dan sosial, tidak seharusnya direkayasa secara formal, tetapi sebaiknya penataannya disesuaikan dengan keperluan masyarakat. ${ }^{4}$

\footnotetext{
${ }^{3}$ Sastrapratedja, Konsep Manusia dalam Antropologi Filsafat dalam Mencari Konsep Manusia Indonesia (Jakarta: Erlangga, 1984)

${ }^{4}$ Mohamad Zen, Orang Laut: Studi Etnopedagogi (Jakarta: Yayasan Bahari Nusantara, , 2002)
}

44 | Jurnal Auladuna 
Potret Kebidupan "Alam": Pendidikan...

Kurikulum pendidikan dapat disusun dengan memasukkan sekelompok tema yang memungkinkan pendidik dan peserta didik sebagai subjek-subjek dalam proses pengetahuan yang mengembangkan kemampuan untuk tahu. Rekayasa kurikulum sekolah yang mengadaptasi nilai-nilai budaya impor kemudian disodorkan kepada anak didik dalam kehidupan sosial-budaya masyarakat tersebut, apalagi kalau kurikulum itu terlalu uniform, kaku, proses belajar mengajar berorientasi pada pengalihan informasi dengan cara penyajian satu arah dan verbalistik. ${ }^{5}$ Pencampuran antara dua sistem budaya yang berbeda yang dipaksakan akan menyebabkan terjadinya kontaminasi budaya, sehingga dapat merusak sistem nilai budaya asli masyarakat tradisional.

Transformasi budaya melalui sekolah dengan menggunakan acuan kurikulum yang tidak berorientasi pada realitas totalitas kehidupan dan lepas dari akar budaya masyarakat, akan sulit mengantisipasi masa depan pengembangan Sumber Daya Manusia. Seperangkat kurikulum baku sebagai instrumen nasional yang diberlakukan secara massal dan kurang memperhatikan relevansinya dengan faktor geografis dan sumber daya alam dapat menyebabkan peserta didik kehilangan kemandirian untuk menangkal dampak kemajuan ilmu pengetahuan dan teknologi. Individu harus memiliki pendidikan yang berwawasan lingkungan, agar ia menjadi sesuai jati dirinya, menyadari keberadaannya sehingga dapat hidup, berubah dan berkembang kemandiriannya.

Upaya pendidikan menurut Fuad Hasan adalah ikhtiar untuk memberi kesempatan "to have" serta memantapkan kesadaran "to be". Sastrapratedja juga berkeyakinan bahwa memiliki "to have" dan ada "to be" merupakan dua kategori fundamental kemanusiaan, agar manusia dapat berada, dapat hidup, dapat berkembang sebagai pribadi maka ia harus memiliki sesuatu. Tugas mulia pendidikan berupaya untuk mengembangkan aspek pribadi manusia, baik jasmaniah maupun rohaniah, agar ia dapat mempertahankan keberadaannya sebagai manusia. Melalui transformasi diharapkan dapat mengubah sikap dan perilaku individu untuk mewujudkan suatu pribadi yang berkualitas sesuai jati diri sebagai manusia seutuhnya.

${ }_{5}^{5}$ Achmad Sanusi, Masalah Mutu Pendidikan dan Kebudayaan (Bandung: P3M Uninus, 1984), 17 
Galuh Dwi Purwasih

\section{Pendidikan Masyarakat Kampung Naga}

Kampung Naga berada di Lembah Sungai Ciwulan, Desa Neglasari, Tasikmalaya, Jawa Barat. Lokasi Kampung Naga sekitar 400 meter dari Jalan Bandung-GarutTasikmalaya. Mata pencaharian utama adalah pertanian. Di lihat dari lokasinya tidak termasuk daerah terisolasi, masuknya pengaruh modern bukan hal yang sukar. Tetapi sistem sosial budayanya masih mempertahankan nilai-nilai adat leluhur. Walaupun masyarakat Kampung Naga termasuk Etnik Sunda, tetapi sistem sosial budayanya memiliki perbedaan dengan masyarakat Etnik Sunda di sekitarnya. Perbedaan itu dapat dilihat dari model, konstruksi dan bahan bangunan rumah, peralatan pertanian dan pakaian yang digunakan. Rumah masyarakat Kampung Naga berupa rumah panggung yang terbuat dari bahan kayu, bambu dan bahan atapnya ijuk serta daun tepus. Alat-alat pertanian yang digunakan masih tradisional, seperti cangkul, bajak, garu. Penduduknya tidak menggunakan alat-alat pertanian modern. Pakaian yang digunakan yaitu baju kampret berwarna putih atau hitam, ikat kepala terbuat dari kain batik, kain dan celana komprang berwarna putih atau hitam. ${ }^{6}$

Aspek-aspek ilmu pengetahuan yang dimiliki masyarakat kampung Naga yang berbeda dari masyarakat lain di sekelilingnya adalah: cara penataan lahan perkampungan, penataan lahan pertanian, cara memelihara kebersihan lingkungan, kepedulian terhadap unsur-unsur ekologis dan keterampilan sebagai pengrajin anyaman bambu. Kampung Naga memiliki satu Sekolah Dasar Negeri, sebagaian besar anak-anak usia sekolah masuk ke sekolah tersebut. Sekolah tersebut melakukan kegiatan belajar mengajar sesuai dengan sekolah-sekolah lain yang menggunakan Standar Nasional. Kurikulum dan mata pelajaran yang diberikan pun sama dengan Sekolah Dasar (SD) lainnya seperti: Bahasa Indonesia, IPA (Sains), IPS (Social Studies), Matematika, Agama, Pendidikan Kewarganegaraan dan Sukan. SD Kampung Naga tidak hanya menngajarkan materi muatan lokal dalam bentuk Bahasa Sunda yang menjadi ciri khas kaum Etnis Sunda (Jawa Barat), tetapi juga muatan lokal pada level darjah satu dalam bentuk kemahiran menganyam bambu serta pertanian dan seni bela diri pencak silat pada darjah empat.

${ }^{6}$ Saripudin Didin, Masyarakat dan Pendidikan: Perspektif Sosiologi (Pahang: Yayasan Istana Abdulaziz, 2008)

46 | Jurnal Auladuna 
Potret Kebidupan "Alam": Pendidikan...

Anak-anak Kampung Naga harus pergi dari luar kampungnya untuk melanjutkan ke Sekolah Menengah Pertama (SMP), karena tidak ada SMP di Kampung Naga. Anak-anak Kampung Naga berbaur dengan anak-anak dari kampung lainnya dalam satu sekolah, begitu juga apabila melanjutkan pada tingkat Sekolah Menengah Atas (SMA). SMP dan SMA tersebut memilliki sitem dan kurikulum yang sama dengan SMP dan SMA lain di Indonesia, hanya untuk muatan lokal adalah Bahasa Sunda.

Hasil penelitian Didin Saripudin pada Tahun 2006 menyebutkan bahwa pengalaman pendidikan generasi muda masyarakat Kampung Naga lebih tinggi dibandingkan dengan ibu bapa mereka. Beberapa orang pemuda sudah mengikuti pendidikan pada tingkat universitas, bahkan dalam program kerjasama Pemuda Indonesia dan Jepang, beberapa orang pemuda Kampung Naga mengikuti pendidikan dan pelatihan di Jepang selama 12 bulan.

Kalangan generasi muda Masyarakat Naga mengalami pergeseran sikap, baik terhadap bentuk-bentuk lama maupun bentuk-bentuk baru. Para pemuda tengah merekontruksi persepsi berkenaan denga nilai-nilai yang paling bermakna bagi dirinya, terutama dalam menyongsong masa depan. Pemuda-pemudi semakin menyadari bahwa eksistensinya tidak hidup dalam Masyarakat Naga sendiri, tetapi berada di tengah-tengah masyarakat lain. Tuntutan-tuntutan harus dipenuhi untuk mempertahanakan keberadaan masyarakat di tengah-tengah kehidupan masyarakat lainnya yang lebih maju. Hasil pengamatan Awan Mutakin dan respon atau sikap masyarakat Naga terhadap unsur-unsur baru seperti Program Panca Usaha Tani (pembaharuan dalam bidang pertanian) adalah positif. Riset tersebut memeperlihatkan bahwa melalui pendidikan yang diperoleh oleh generasi muda Masyarakat Naga, maka mulai terjadi transformasi budaya modern, terutama dalam mengembangkan pemilikan dan pemanfaatan teknologi di kalangan Masayarakat Naga.

\section{Pendidikan Orang Lout}

Kelompok Orang Laut di Kepulauan Riau disebut oleh masyarakat setempat sesuai dengan nama pulau yang mereka tempati misalnya Orang Mantang tinggal di sekitar Pulau Mantang, Orang Barok bermukim di Selat Barok, Orang Galang tinggal di sekita Pulau Galang, Orang Pusek berdiam di sekitar Pulau Pusek. Wilayah Indonesia bagian Timur 


\section{Galuh Dwi Purwasih}

mengenal Orang Laut sebagai Orang Bajau yang dapat ditemukan di perairan Selat Makassar di Pantai Timur Kalimantan, di Teluk Bone, di wilayah Nusa Tenggara Timur, di Teluk Tomini, di Maluku Utara dan di perairan Laut Sulawesi. Orang Laut adalah sekelompok manusia yang berbudaya laut (aquaculture) baik sebagai pengembara laut dalam sampan Kajang, semi menetap di pemukiman rumah terapung, maupun menetap di pesisir pantai atau daratan pulau-pulau terpencil.

Penelitian pendidikan pada Orang Laut di Kepulauan Riau menunjukkan bahwa putus sekolah dasar masih cukup tinggi di kalangan anak-anak usia 9-10 tahun. Lingkungan alamnya, terutama di sektor "aquaculture" dengan karakteristik ekosistemnya telah memaksa mereka memilih kehidupan praktis di lautan daripada terbelenggu di bangku sekolah. Jalur pendidikan sekolah yang secara formal terpaku pada seperangkat kurikulum baku, batas usia dan waktu belajar yang diprogramkan secara ketat, belum menarik minat belajar anak-anak di sana. Alternatif yang mungkin dapat dipertimbangkan adalah dengan mengembangkan jalur pendidikan luar sekolah yang tidak terlalu mengekang aktivitas peserta didik untuk menekuni kehidupan nyata di lingkungannya.

Pendidikan sekolah bukanlah satu-satunya upaya untuk meningkatkan kualitas Sumber Daya Manusia dan tidak perlu dipaksakan kepada suatu masyarakat tradisional yang telah memiliki pendidikan tradisi dan sistem belajar asli. Sistem belajar asli dalam masyarakat tradisional secara dominan cenderung dipengaruhi oleh proses belajar melalui pengalaman konkret (concrete experiences), di mana mereka menangkap sesuatu objek apa adanya, tergantung penglihatan. Proses belajar demikian dapat dilihat dalam kehidupan Orang Laut yang masih mengembara di lautan, semi menetap dan menetap di gugusan pulau-pulau terpencil. Kebisaaan mengembara di lautan, telah menempa dan membentuk sikap serta perilaku Orang laut untuk beradaptasi dengan lingkungan pengembaraan yang selalu dipengaruhi oleh pergeseran angin dan musim. Pengenalan dan pemahaman mereka terhadap siklus ikan dan biota laut telah mereka pelajari sejak anak-anak secara turuntemurun melalui sistem belajar asli (indigenous learning system) yang diajarkan oleh orang tuanya. $^{7}$

Kemampuan mereka menangkap gejala-gejala alam tanpa makna apa adanya (apprehension) merupakan proses belajar melalui pengalaman konkret (concrete

\footnotetext{
${ }^{7}$ Nazili, Pendidikan dan Masyarakat (Yogyakarta: Bina Usaha, 1989)
}

48 | Jurnal Auladuna 
Potret Kebidupan "Alam": Pendidikan...

experiences) yang berkembang dalam sistem belajar asli lingkungan keluarga dan masyarakat. Pengetahuan mengenai letak dan susunan bintang-bintang yang dipelajari melalui pengalaman konkret merupakan pedoman yang dapat menuntun mereka untuk menentukan waktu, keadaan cuaca, siklus ikan, arah pelayaran, pergeseran angin, peredaran arus, perubahan musim, dan sebagai petanda alam yang selalu dikaitkan dengan ruang gerak dan aktivitas sosial-budaya dalam kehidupan kelompok.

Indra Orang Laut sangat sensitif terhadap situasi lingkungan alam yang berubah dan mempengaruhi kehidupan sehari-hari. Orang Laut secara intuitif dapat meraba getaran dan kondisi air laut dengan menggunakan sentuhan tangan atau kaki untuk menentukan siklus ikan berdasarkan temperatur air dan peredaran arus laut. Penciuman Orang Laut ternyata peka terhadap hembusan angin yang membawa aroma laut sebagai petanda perubahan musim. Orang Laut mempunyai kemampuan mengamati tanda-tanda yang menuntunnya untuk menentukan secara tepat lokasi berbagai biota laut yang terdapat di sekitar terumbu karang. Keterampilan Orang Laut mengendalikan perahu dalam cuaca jelek, kemampuan bertahan dalam air dan menentukan tempat-tempat perburuan ikan dan biota laut serta kemampuan membaca gejala-gejala alam dan menafsirkannya merupakan pendidikan tradisi yang mereka peroleh sejak masa kanak-kanak melalui proses sosialisasi dalam lingkungan keluarga, masyarakat dan alam sekitar. Sistem pengetahuan gejala alam itu dimiliki secara turun-temurun melalui suatu proses sosialisasi dan langsung diterapkan dalam kehidupan sehari-hari, sejak awal pada masa kanak-kanak hingga akhir hayat.

Kelompok Orang Laut yang hidupnya tergantung pada sektor "aquaculture", memiliki sejumlah media belajar berupa: cerita rakyat, pantun-pantun, petatah-petitih, peribahasa dan nyanyian ritual. Sistem belajar asli ini dilengkapi dengan seperangkat bakuan nilai, berupa pantang-larang sebagai tuntunan dalam ikatan kelompok dan tanggungjawab sosial, seperti: menghormati leluhur, orang tua, bertingkah laku sesuai tingkat usia, mematuhi norma-norma yang berlaku, saling memberi dan berbagi. Francisco pada Tahun 1918 mengidentifikasi paling sedikit ada tiga mekanisme dari sistem belajar asli (indigenous learning system) yaitu "life cycle complex", "social control mechanism" dan "ritual" yang diwujudkan dalam sistem kepercayaan (belief sistem) dari orang-orang asli. Anak-anak mematuhi pantang-larang, mengikuti upacara ritual, dan melakukan 


\section{Galuh Dwi Purwasih}

tindak-tanduk yang dapat diterima dalam masyarakat melalui sosialisasi dari lingkungan keluarga. Kaum ini menerima dan mempelajari nilai-nilai dari masyarakat yang dibutuhkannya sebagai mekanisme kehidupan dalam kelompok.

Keberadaan sekolah di pemukiman Orang Laut yang terletak di pulau-pulau terpencil dapat menyita waktu anak-anak usia sekolah untuk akrab dengan lingkungan alam, karena dibelenggu oleh kegiatan rutinitas dalam proses belajar mengajar di sekolah. Lingkungan sekolah dan masyarakat yang berbeda di mana transformasi telah menempatkan anak-anak dalam menentukan pilihan sesuai keperluan praktis yang lebih menguntungkan menurut pertimbangan rasional mereka, walaupun keputusan tersebut tidak rasional menurut pertimbangan penyelenggara pendidikan. Departemen Pendidikan Indonesia mengembangkan pendidikan luar sekolah (non-formal) yang lebih fleksibel dibandingkan dengan pendidikan sekolah dari segi kurikulum, waktu, tempat, pelajar dan tenaga pendidik. Pengaturan pendidikan luar sekolah diberikan kewenangan kepada pemerintah daerah (desentralisasi) untuk mengembangkannya sesuai dengan karakteristik lingkungan alamiah, sosial dan budaya. ${ }^{8}$

Masyarakat dilibatkan secara lansung dalam pengelolaan pendidikan melalui pendidikan luar sekolah ini dengan mendirikan Sanggar Kegiatan Belajar (SKB) dan Pusat Kegiatan Belajar Masyarakat (PKBM). Masyarakat sendiri yang merencanakan, melaksanakan dan mengawasi kegiatannya, pemerintah hanya mendukung dan memfasilitasi. Pendidikan luar sekolah terdiri dari program Paket A (setara sekolah dasar), Paket B (setara sekolah menengah pertama), Paket C (setara sekolah menengah atas) dan berbagai keterampilan hidup. Ijazah (sijil) dari program pendidikan luar sekolah diiktirafkan sama dengan pendidikan sekolah, sehingga jika ada pelajar yang akan melanjutkan ke tingkat universitas pun tidak menjadi masalah.

Para guru (tutor) pada pendidikan luar sekolah selain diangkat oleh pemerintah, juga melibatkan masyarakat itu sendiri dan pihak NGO. Tempat belajar tidak selalu harus di gedung sekolah, tetapi boleh di rumah, di atas perahu, di bawah pokok atau di tempattempat yang memungkinkan sesuai dengan lingkungannya. Siswa selain diajarkan kemampuan kemahiran 3M (membaca, menulis, menghitung) sesuai dengan kurikulum

${ }^{8}$ Koentjaraningrat dkk, Membangun Masyarakat Terasing di dalam Masyarakat terasing di Indonesia (Jakarta: Gramedia Pustaka Utama, 1993)

50 | Jurnal Auladuna 
Potret Kebidupan "Alam": Pendidikan...

sekolah, juga di ajari materi pelajaran mengenai geometri, navigasi, biologi laut, oseanografi, ilmu perbintangan, dan pengolahan ikan serta biota laut lain sesuai dengan perkembangan anak didik.

\section{PENUTUP}

\section{Simpulan}

Masyarakat tradisional di Indonesia masih banyak yang berada dalam kelompokkelompok kecil di desa-desa pedalaman dan gugusan pulau terpencil. Departemen Pendidikan Nasional Indonesia mengembangkan dua jalur pendidikan, yakni pendidikan melalui sekolah dan pendidikan luar sekolah (non-formal) untuk memenuhi hak warga negara dalam memperoleh pengkhidmatan pendidikan, terutama pendidikan dasar 9 tahun. Setiap jalur pendidikan yang ditawarkan kepada kelompok masyarakat tradisional terpencil geografis dan sosial budaya diharuskan mengangkat sistem belajar asli (indigenous learning system) yang telah tumbuh sebagai potensi pendidikan dalam kehidupan mereka. Pendidikan terpadu berwawasan lingkungan akan menciptakan suasana keserasian belajar yang dapat menghindarkan terjadinya kontaminasi atau benturan-benturan antar nilai-nilai baru yang ditawarkan secara nasional dengan nilai-nilai lokal.

Masyarakat tradisional yang sudah dapat menerima sekolah seperti Masyarakat Kampung Naga, kurikulum sekolah tersebut dapat dimasukkan pengetahuan lokal atau kearifan lokal (local knowledge atau local wisdom) dalam mata pelajaran muatan lokal, sebagai sumber inovasi dan keterampilan yang dapat diberdayakan demi kesejahteraan masyarakat. Keberadaan sekolah di pemukiman Orang Laut yang terletak di pualu-pulau terpencil dapat menyita waktu anak-anak usia sekolah untuk akrab dengan lingkungan alamnya, karena dibelenggu oleh kegiatan rutinitas dalam proses belajar-mengajar di sekolah, pendidikan luar sekolah (non-formal) dapat menjadi salah satu alternatif. Para siswa dapat belajar tanpa batas tempat, waktu, umur, lingkungan sosial budaya di mana pun siswa berada dan bekerja, di bawah bimbingan seorang tutor pegawai negeri, tokoh masyarakat atau NGO.

Operasionaliasasi sistem pendidikan nasional diharapkan dapat menjabarkan ide vital dan nilai-nilai sentral bangsa Indonesia dengan tidak mengabaikan sistem belajar asli sebagai suatu potensi yang sudah berakar dalam pendidikan tradisi masyarakat tradisional. 


\section{Galuh Dwi Purwasih}

Sistem belajar asli perlu dijaga untuk diangkat ke permukaan sejauh itu tidak bertentangan dengan ide nasional, agar proses pendidikan yang terjadi dalam masyarakat tradisional tetap utuh dalam negara kesatuan. Setiap proses pendidikan pada hakikatnya merupakan ikhtiar untuk mengarahkan dan mengerahkan dua daya: daya untuk melestarikan dan daya untuk memajukan.

Peningkatkan perkhidmatan pendidikan, terutama pendidikan dasar 9 tahun bagi masyarakat terasing di Indonesia, penulis mengusulkan beberapa cadangan:

1. Wajib belajar sekolah dasar tidak harus ditentukan seragam melalui lingkungan sekolah saja, boleh dilakukan melalui jalur pendidikan luar sekolah (non-formal), tetapi jalur pendidikan luar sekolah bukanlah sekedar pelengkap, tetapi harus mendapatkan tempat yang sama. Kesenjangan peluang perolehan dari sekolah melalui jalur ini dapat diupayakan secara terpadu agar masyarakat dapat menentukan sendiri alternatif pilihan sebagai suatu jalan mendapatkan kesempatan belajar sesuai dengan tuntutan program wajib belajar dalam mencerdaskan kehidupan bangsa dan meningkatkan produktivitas individu dalam masyarakat di daerah terpencil, kepulauan dan daerah perbatasan. Kebijakan dan penyelenggaraan pendidikan berwawasan lingkungan secara terpadu perlu meningkatakan keterlibatan seluruh aktivitas masyarakat melalui Lembaga Ketahanan Masyarakat Desa (LKMD), Lembaga Adat dan NGO, agar upaya transformasi dapat menyentuh dan menjadi keperluan setiap individu masyarakat.

2. Keberadaan sekolah di desa-desa pedalaman dan pulau-pulau terpencil dengan fasilitas serba kekurangan (guru, buku-buku dan peralatan belajar) selama ini merupakan suatu kendala yang sukar diatasi. Setiap pulau-pulau terpencil yang ribuan jumlahnya tidak perlu diberikan seperangkat alat sekolah, cukup di kota kecamatan saja, karena biaya pengelolaannya cukup tinggi. Perlu dipertimbangkan pengelolaan sistem belajar jarak jauh melalui perangkat telekomunikasi satelit seperti: radio dan televisi serta pendidikan tenaga surya yang dimonitoring oleh perangkat studio mini interaktif sebagai pembelajaran tanpa batas yang dapat menjangkau desa-desa pedalaman dan pulau-pulau terpencil.

3. Bagi kelompok masyarakat pengembara (nomad) di darat dan lautan, perlu disiapkan suatu program pendidikan bermusim sesuai keadaan musim yang mana mengharuskan para nomad menetap, seperti diwaktu kemarau panjang dan lautan sedang kencang 
Potret Kebidupan "Alam": Pendidikan...

ombaknya. Pada musim-musim tertentu biasanya pengembara lautan tidak turun ke laut dan mereka menetap pada pulau-pulau tertentu menunggu cuaca, baik untuk melakukan perburuan kembali. Pemaksaan untuk merubah kebiasaan mengembara dengan menetap di pemukiman yang disediakan merupakan masalah tersendiri dan memerlukan suatu pendekatan persuasif dalam mengajak serta membujuknya agar hidup menetap. Para nomad bukan bermaksud tidak memikirkan untuk bertempat tinggal secara menetap, tetapi kemiskinan yang membelenggu menyebabkan masyarakat pengembara bersikap pragmatik untuk melakukan kegiatan praktis yang secara ekonomis lebih menguntungkan dan dapat mengurangi beban kehidupan hariannya.

\section{DAFTAR PUSTAKA}

Koentjaraningrat, dkk. Membangun Masyarakat Terasing di dalam Masyarakat Terasing di Indonesia. Jakarta: Gramedia Pustaka Utama, 1993.

Nazili, Pendidikan dan Masyarakat. Yogyakarta: Bina Usaha, 1989.

Sanusi, Achmad. Masalah Mutu Pendidikan dan Kebudayaan. Bandung: P3M Uninus, 1984.

Saripudin, Didin. Masyarakat dan Pendidikan: Perspektif Sosiologi. Pahang: Yayasan Istana Abdulaziz, 2008.

Zen ,Mohamad. Orang Laut: Studi Etnopedagogi. (Jakarta: Yayasan Bahari Nusantara, 2002. 